DE DE GRUYTER

OPEN

DOI: $10.1515 /$ jolace-2016-0031

\title{
The intercultural component in an EFL course-book package
}

\author{
Zuzana Sándorová, Constantine the Philosopher University, Slovakia \\ zsandorova@ukf.sk
}

\begin{abstract}
Along with mastery of the grammar and vocabulary of a given language, contemporary students are also expected to acquire intercultural communicative competence (ICC), i.e., the ability to use the language efficiently with regard to the sociocultural background of the communicative situation. This requirement should also be reflected in FL course-books, which are considered to be fundamental didactic tools in FL education, even in an era of information communication technologies. Therefore, the aim of the present paper is to report the results of the research focused on the investigation of intercultural component in the New Opportunities Pre-Intermediate and Intermediate course-book packages.

To validate the findings of the content analysis, as the main research method, the method of triangulation was used, i.e., the results of the course-book package analyses were compared with those of observation and interview analyses. The findings of the research revealed that in the investigated course-book packages only some aspects of the intercultural component could be considered relevant because they were suitably treated.

Key words: FL course-books, culture and language, content analysis, intercultural communicative competence

\section{Introduction}

It seems that due to massive migration flows and signs of increasing ethnocentrism, intercultural communicative competence (ICC) is gaining more and more significance in contemporary globalized world. However, "intercultural knowledge and intercultural communication skills do not come naturally; they have to be acquired through conscious learning" (Liu et al., 2011, p. 26). Undoubtedly, FL education can enhance the acquisition of these competences to a great extent by systematically integrating the intercultural aspects into the teaching of linguistic issues.

As FL course-books still represent the core of FL education, they have a great impact on what is taught and how it is taught in the FL classroom (Byram, 1989, Davcheva et al., 2003). According to the research findings, they have the power to
\end{abstract}


influence the perception of the target culture and the attitude towards it, as well as the whole process of learning the target language and culture. Therefore, it is of particular importance that FL course-books contribute to the development of ICC. However, the research on FL textbooks used in Slovakia, especially from the point of view of their intercultural content, cannot be regarded as sufficient. In order to fill this gap, the aim of the research was to investigate the culture-related aspects in the second most often chosen EFL course-book package in Slovakia (based on a questionnaire survey carried out in 2013) (Sándorová, 2013).

The paper is divided into two main parts: the theoretical background of the study and the research part. The former is concerned with the content and the structure of ICC, as the keyword of the research, as well as with the role of FL textbooks in fostering ICC. Furthermore, some proposals by intercultural scholars with regard to the content of FL course-books and its investigation are also discussed. The latter, in addition to the methodology of the research, contains the findings and conclusions of the research.

\section{Literature review}

\section{Understanding intercultural communicative competence}

A discrepancy can be detected between intercultural scholars in relation to the use of the term intercultural communicative competence. On the one hand, some scholars find it important to distinguish between communicative competence, cultural competence, intercultural competence and intercultural communicative competence. On the other hand, as in the examples below, there are scholars who use the terms communicative competence and intercultural communicative competence interchangeably, as their definitions of the former also comprise features of the latter.

According to the Council of Europe (2001, p. 9) communicative competence refers to a person's ability to act in a FL in a linguistically, socio-linguistically and pragmatically appropriate way"; whereas cultural competence can be defined "as knowledge of the life and institutions of the target culture" (Corbett, 2003, p. 31). In addition, intercultural competence is the ability to interact in one's own language with people from another country and culture, using one's own knowledge of the given country and culture (Byram, 1991). Finally, intercultural communicative competence means the ability to interact with people from another country in a foreign language. "The knowledge of another culture is linked to the language competence through the ability to use language appropriately sociolinguistic and discourse competence - and the awareness of the specific meanings, values and connotations of the language" (Byram, ibid., p. 71). Similarly, Sercu (2005) argues that intercultural communicative competence is based upon communicative competence and enriches it by incorporating intercultural competence. 
The concept of communicative competence was established by Hymes (1974, in Brown, 2000, Hall, ibid., p. 105-106), who claimed that Chomsky's theory of language universals, as an innate property of mind, could not explain the knowledge and skills which individuals must have in order to be able to "understand and use linguistic resources in ways that are structurally well formed, socially and contextually appropriate, and culturally feasible in communicative contexts constitutive of the different groups and communities of which the individuals are members". According to Hymes, communicative competence has four dimensions. The first is called systematic potential and it refers to the basic knowledge and ability to use a particular language. The second dimension is appropriateness, which can be understood as the ability to use language appropriately with regard to its contextual features. Occurrence which can be defined as "knowledge of whether and to what extent action is taken with language, and the ability to use language to take such action", is the third dimension of communicative competence. Finally, feasibility includes "knowledge of whether and to what extent something is possible, and the ability to be practical or feasible" (Hall, ibid., p. 105-106).

Jong (1996) defines communicative competence as the ability to use a foreign language effectively, which in addition to knowledge of vocabulary and grammar, also comprises the knowledge of foreign culture in terms of issues that should be avoided, what topics are considered safe or how to cope with misunderstandings that might occur during intercultural interactions. Similarly, Kachru and Nelson (1996, p. 90) also understand communicative competence in terms of appropriateness, with regard to "all facets of language, including rate of speech and level or register of lexis"; hence, the ability to recognize the different types of situations is equally important.

According to Saville-Troike (1996, p. 362), communicative competence, which consists of linguistic knowledge, interaction skills and cultural knowledge, can be "broadly defined as what a speaker needs to know to communicate appropriately within a particular speech community". Linguistic knowledge, as the first dimension, in addition to the "traditional elements", such as grammar, lexicon or phonology, should also comprise paralinguistic and nonverbal phenomena. Interaction skills include a wide range of knowledge, which can be understood in terms of expectations or conventions in the target culture, such as when to speak and when it is better to be silent, what nonverbal communication is appropriate in certain situations, how to take the floor and how to request, and the like. The last dimension, cultural knowledge, involves all aspects of culture, but especially the social structure of a particular speech community and "the values and attitudes held about language and ways of speaking" (ibid., p. 367).

As it can be seen, all the above discussed perceptions of communicative competence emphasize the ability of appropriate language use in a particular 
social setting. The central idea of these definitions can also be well-illustrated by Byram's model of ICC (1997, p. 73), consisting of four dimensions, i.e., linguistic competence, sociolinguistic competence, discourse competence and intercultural competence (see Figure 1). According to him, intercultural competence comprises the following five factors: attitudes (savoir être), knowledge (savoirs), skills of interpreting and relating (savoir comprendre) and skills of discovery and interaction (savoir apprendre/faire), as well as critical cultural awareness (savoir s'engager). Attitudes refer to "curiosity and openness, readiness to suspend disbelief about other cultures and belief about one's own" (Byram, 1991, p. 50). It means, for example, that the intercultural speaker is willing to share their experience about others' daily life, is interested in others' opinions on familiar or unfamiliar issues, or takes into consideration expectations about appropriate behaviour in a particular situation.

Figure 1: Model of intercultural communicative competence (Byram, 1997, p. 73)

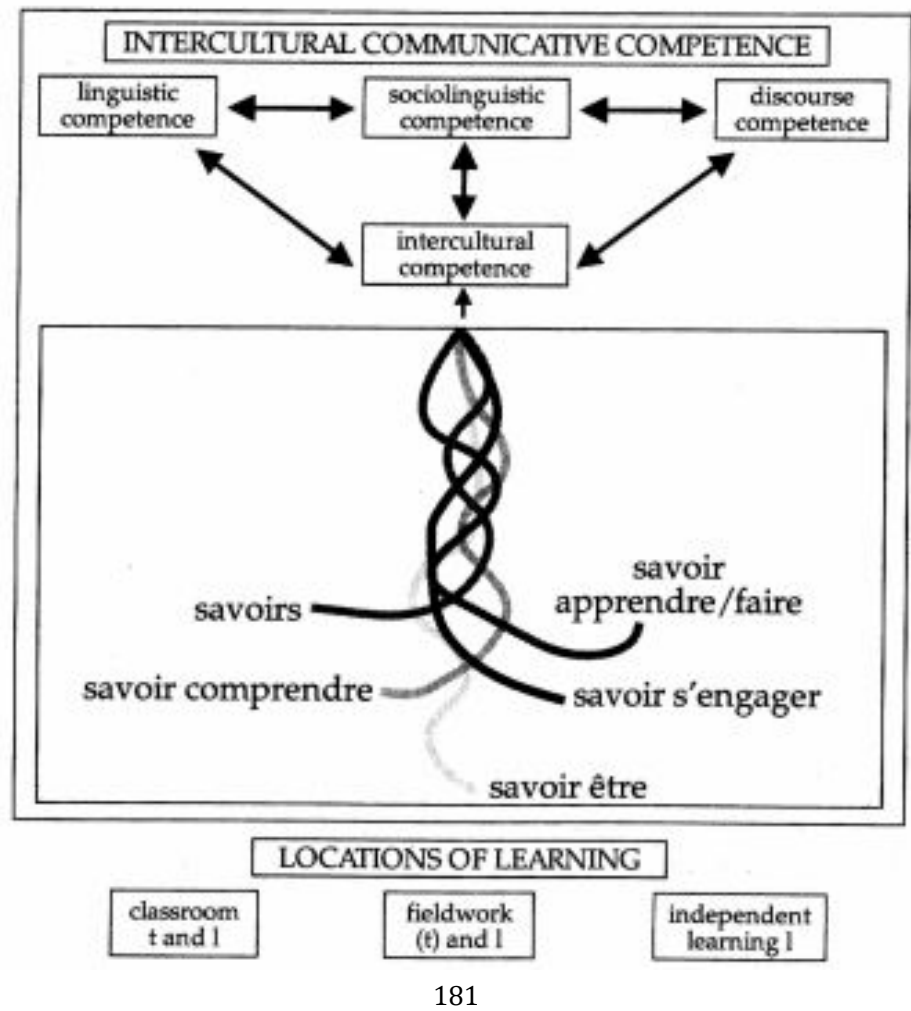


Knowledge means the knowledge "of social groups and their products and practices in one's own and in one's interlocutor's country, and of the general processes of societal and individual interaction" (ibid., p. 51). For instance, the intercultural speaker has familiarity with the historical events, cultural products, institutions or geographical features of his/her own and the interlocutor's country. Skills of interpreting and relating referring to "ability to interpret a document or event from another culture, to explain it and relate it to documents from one's own" (ibid., p. 52), comprise, for example, the readiness to identify the sources of misunderstandings and address them. Skills of discovery and interaction stand for the "ability to acquire new knowledge of a culture and cultural practices and the ability to operate knowledge, attitudes and skills under the constraints of real-time communication and interaction" (ibid., p. 52), e.g., identifying contemporary as well as historical relationships between cultures, behaving in accordance with the conventions of verbal and nonverbal interaction, etc. Finally, critical cultural awareness (Byram, 1997, p. 63) refers to "an ability to evaluate, critically and on the basis of explicit criteria, perspectives, practices and products in one's own and other cultures and countries"; for instance, in terms of identifying and interpreting values in events or being aware of potential conflicts between ideologies.

\section{Intercultural communicative competences in the CEFR}

Byram's model, acknowledged by various scholars (e.g., Corbett, 2003, Sercu, 2005), has also been accepted by the Common European Framework of Reference for Languages: Learning, Teaching, Assessment (CEFR, 2001) as the main curricular document of the European Union in the field of FL education, which proposes a framework for the elaboration of curricular documents, course syllabi, examinations as well as teaching materials for all European countries. It defines six reference levels of language proficiency, from Breakthrough (A1) and Waystage (A2), through Threshold (B1) and Vantage (B2), to Effective Mastery (C1) and Operational Proficiency (C2), providing illustrative scales of descriptors for each of them, in terms of what an FL user "can do" at a particular stage. In addition, with regard to the components of intercultural communicative competences, a set of minimum requirements to "survive" in the target country, i.e., for the Threshold level (B1), was elaborated and published as Threshold 1990 by J. A. van Ek and John Trim (Jong, 1996).

According to the CEFR (ibid.), all skills acquired by a person can contribute to the development of communicative competence; however, we have to differentiate between more closely connected abilities and less closely related skills. In these 
terms we have to distinguish between general and communicative language competences. General competences consist of declarative knowledge (savoir), skills and know-how (savoir faire), "existential" competence (savoir être) and the ability to learn (savoir apprendre). Communicative language competence is a sum of more language-related components which can be divided into linguistic, sociolinguistic and pragmatic competences.

Declarative knowledge comprises knowledge of the world, sociocultural knowledge and intercultural awareness. In the category of knowledge of the world, the CEFR (2001, p. 102) emphasizes that "of considerable importance to the learner of a particular language is factual knowledge concerning the country or countries in which the language is spoken, such as its major geographical, environmental, demographic, economic and political features". With regard to sociocultural knowledge, the documents highlights that FL learners often lack even basic knowledge and they are frequently influenced by stereotypes; hence, acquisition of this type of knowledge deserves considerable attention in FL teaching. It involves aspects of everyday living, such as food and drink, meal times, table manners, public holidays, working hours, leisure activities or living conditions, i.e., housing, welfare arrangements and living standards (ibid.). Learners must also get acquainted with some unwritten rules of behaviour of the target culture, such as punctuality, getting and giving presents, dress code, behavioural and conversational conventions and taboos, length of stay, leavetaking, etc. (ibid.). In addition, values and beliefs in relation to social class, occupational groups, regional cultures, tradition and social change, history, politics, religion, humour, etc., that are hidden under the surface have a strong impact on the communication, as well. Furthermore, one must be aware of paralinguistic characteristics, such as body language, extra-linguistic speech sounds and prosodic qualities, as well as paralinguistic features of written texts. Word-completing practical actions comprise pointing, demonstration and clearly observable activities; body language refers to gestures, facial expressions, posture, eye contact, body contact, proxemics; extra-linguistic speech includes requesting silence, expressing approval, public and polite disapproval, disgust or disgruntlement. Furthermore, features of prosody, such as voice quality, loudness, pitch (intonation), stress, rhythm or length, can also play a "paralinguistic role". Last but not least, intercultural awareness, as the third aspect of declarative knowledge, stands for the awareness and understanding of the similarities and differences between the target and the home culture. However, it does not relate only to the distinctive features at national level, also includes regional and social variations in both communities.

The "skills and know-how" group stands for a sum of practical skills and knowhow and intercultural skills and know-how. In the category of the former, social skills have to be mentioned, comprising the ability to act in correspondence with 
the expectations related to foreigners. The latter comprise "the ability to bring the culture of origin and the foreign culture into relation with each other" (ibid, p. 104), as well as to be culturally sensitive and apply a range of strategies to establish and maintain contact with the members of the target community. In addition, FL learners must also be equipped with the ability to overcome stereotypes.

Existential competence is connected with the individuals' personality, as the ability to communicate is also affected by factors such as attitudes, motivations, values, beliefs, cognitive styles and personality types. Attitudes refer to the FL learner's degree of "openness towards, and interest in new experiences, other persons, ideas, peoples, societies and cultures; willingness to relativise one's own cultural viewpoint and cultural value-system; as well as willingness and ability to distance oneself from conventional attitudes to cultural difference" (ibid., p. 105).

The ability to learn refers to language and communication awareness, general phonetic awareness and skills, which imply "sensitivity to language and language use" (ibid., p. 107), as well as to study and heuristic skills, i.e., the ability to cope with new experience (language, people, behaviour) by observing and inferring, etc.

Linguistic competences include lexical, grammatical, semantic, phonological, orthographic and orthoepic competences. Lexical competence refers to the ability to use the lexical elements of a language, such as fixed expressions and single words, together with their grammatical elements. Grammatical competence is the mastery of structure (syntax) and form (morphology) and is related to grammatical accuracy in using different elements, categories, classes, structures, processes and relations of the language. Semantic competences is connected with the awareness and control of the lexical, grammatical and pragmatic meaning of words. Phonological competences stands for the perception and production of phonemes, the awareness of their distinctive features and the ability to use prosodic qualities. Orthographic competence refers to the knowledge of and skill to apply the rules of written language, whereas orthoepic competence is connected with the sound realisation of language.

Sociolinguistic competences involves "linguistic markers of social relations, politeness conventions, expressions of folk-wisdom, register differences and dialect and accent" (ibid., p. 118). Linguistic markers of social relations comprise the use of different forms of greetings (when arriving, leaving, etc.), ways of addressing (frozen, formal, informal, familiar, peremptory, insult) and the use of expletives (ibid.). Politeness conventions refer to both "positive" politeness (e.g., expressing gratitude, offering gifts, etc.) and "negative" politeness (e.g., apologizing, expressing regret, etc.), as well as the appropriate use of such expressions as "please" and "thank you". In addition, FL speaker must also be aware of direct commands, strong complaints and reprimands, venting anger, impatience or asserting superiority being considered impolite behaviour (ibid.). 
Expressions of folk wisdom include proverbs, idioms, familiar quotations, expressions of belief, attitudes and values, etc. Whereas proverbs are defined as "pithy sayings expressing general truth, popular wisdom or advice" (Kvetko, 1996, p. 90), idioms have certain features that make them different from other lexical units. They consist of more than one word, however, they function as single lexical units. In addition, they cannot be translated literally, for they have a unique and figurative meaning (ibid.). Phrasal verbs and similes rank among idioms, regarded as a special group of fixed expressions. The former are combinations of verbs and particles (e.g., look for, turn on, etc.), and their meaning may be opaque. The latter are "used to describe one thing by comparing it to another", e.g., "as busy as a bee", etc. (ibid., p. 90). Furthermore, there are also so-called "minimal idioms", idiomatic phrases consisting of only one content word, e.g., "of course", "at last", "at all", etc. (ibid.). The expressions of belief most frequently function as weather-saws, and the expressions of attitude can be understood as clichés.

Register differences are connected mainly with the level of formality distinguished as: frozen, formal, neutral, informal, familiar and intimate. The appropriate use of register is extremely important as it can lead to misunderstandings and make the speaker look ridiculous when wrong words are selected. Sociolinguistic competence also refers to the ability to recognize the differences between social, geographical and regional varieties of a language, as well as between different subcultures (in vocabulary, grammar, pronunciation and paralinguistic characteristics).

Pragmatic competences, refers to the ability to use the language appropriately for particular purposes with regard to the sociocultural context and can further be divided into discourse, functional and design competence. Discourse competence stands for the ability to produce a text, both written and spoken, with regard to "thematic organisation, coherence and cohesion, logical ordering, style and register, rhetorical effectiveness" (ibid., p. 123), and it also includes the aspect of text design, i.e. the way in which information is structured in terms of different macro-functions (description, narrative, exposition, etc.), as well as the way in which stories, anecdotes, jokes, etc., are told, and the layout, signposting and sequencing of written texts.

The second component of pragmatic competences, functional competence, is the ability to use the language for different purposes (both in written and spoken form) and comprises "micro-functions". A "macro-function is characterised by its interactional structure" and consists of several micro-functions. Micro-functions comprise a wide range of various types of utterances (including skills from looking for information and reporting, through expressing and finding out different attitudes, suasion and socializing, to structuring discourse and communication repair). Design competence means that macro-functions are patterned on the socalled "interaction schemata", i.e., patterns of social interaction structured by the 
communication partners in turns (e.g. between a shop assistant and a customer or between a doctor and a patient, etc.).

To summarize, apparently, the framework provided by the CEFR (ibid.) does not rely only on developing communicative competence, understood as the ability to use the language in different situations of communication (Homolová, 2003). It also contains a wide range of other skills and knowledge to be acquired by a FL speaker in order to become an interculturally competent speaker of the target language. Consequently, "the objective of language learning is no longer defined as solely the acquisition of communicative competence. Teachers are now required to teach intercultural communicative competence" (Sercu, 2005, p. 2).

\section{FL course-books in developing intercultural communicative competence}

Since FL course-books "present the country in a nut-shell" (Risager, 1991, p. 191), they can have a great impact on FL learners' intercultural knowledge and skills, as well as on their attitudes towards the target culture. Buttjes (1991) claims that the acquisition of the target language can be enhanced by culturally rich textbooks and a socially realistic presentation in them. Davcheva et al. (2003, p. 91) emphasize that FL "textbooks can significantly influence the way culture is taught in the FL classroom". Byram (1991) based on his research adds that the dominant role of FL course-books in developing ICC should be taken seriously by all those involved in FL education. These opinions are also supported by empirical research on the extent to which FL textbooks are used to teach cultural aspects in FL classrooms and what impact they have on FL learners' perception of the target culture. For example, the aim of the research project called "The Durham Project" conducted by Byram et al. (1991), was to reveal the impact a "French as FL" textbook had on learners' tolerance of French people and their knowledge of French culture. It was based on case studies of two secondary comprehensive schools, the subjects were 200 students who were tested and 100 of whom were also interviewed. The results of the field notes from over eight months' classroom observation revealed that textbooks played a determining and dominant role in the forming FL leaners' attitudes towards French culture. In addition, Davcheva et al. (2003) "examined and compared views and practices of FL teachers with regard to the cultural dimension of the teaching materials they used in class". Results showed that teachers, regardless of their country of origin, relied chiefly on FL textbooks when teaching cultural aspects.

Based on the abovementioned studies and viewpoints, it seems that one of the new roles which FL textbooks should gradually acquire is that of mediator between the home and the target culture (Risager, ibid.). Despite the vast amount of recommendations on the content and methodology of teaching cultural issues in general, the list of proposals given for the intercultural content of FL course- 
books is more limited. Yet, the following part discusses suggestions which address the content of both FL lessons and FL teaching materials.

Seelye (1997) notes that it is not enough for FL course-books to have footnotes or endnotes; they should also offer experiential activities which develop FL learners' skills using the cultural context to decode the meaning in communication.

Concerning the methods of teaching the cultural input in FL course-books, according to Hatoss (2004), the following two different aspects have to be taken into consideration:

1. Implicit versus explicit teaching of the cultural input

2. Cognitive versus experiential teaching of the cultural input.

Culture is taught explicitly when students are "constantly confronted with different values, different perspectives, traditions, and the ways of interpreting the world" in order to become "critical intercultural speakers" (ibid., p. 29). In these terms, it is also important to consider whether the learners are only exposed to the cultural input, or they are provided with the opportunity to reflect on it. Another confronting way of teaching cultural input is building leaners' awareness of their own culture as an essential part of developing their intercultural competences. However, the constant comparison of the learners' first culture to the target culture should not happen in a competitive way, and EFL courses should not suggest the replacement of the students' own culture. With regard to cognitive versus experiential teaching, Hatoss (ibid.) outlines that both methods are equally important, yet modern teaching approaches emphasize the experiential ways of teaching as they make learning more effective.

Another interesting viewpoint is offered by Brooks (1997, p. 25), who claims that "as long as we provide our students only with the facts of history and geography, economics and sociology, as long as we provide them only with a knowledge of the sophisticated structures of society such as law and medicine, or examples and appreciative comments on artistic creations such as poems, castles, or oil paintings, we have not yet provided them with an intimate view of where life's action is, where the individual and the social order come together, where self meets life". To support this idea, Brooks constructed a list of 10 issues, based on Hall's scheme presented in The Silent Language (1959, in Brooks, ibid., p. 27-29). The list contains the following issues:

1. Symbolism: e.g., literature, art, myths, politics and religion;

2. Value: e.g., personal preference, morality, philosophy, etc.;

3. Authority: e.g., whose world is accepted at different stages in one's life, etc.;

4. Order: e.g., dispositions towards a clear arrangements of thoughts, etc.;

5. Ceremony: e.g., dress, rituals;

6. Love: e.g., parent and child, husband and wife;

7. Honour: e.g., attitude towards ourselves, our families, friends or country; 
8. Humour: e.g., what is witty and how it differs from one culture to another;

9. Beauty: e.g., in terms of the aesthetic sense of products of the human mind and hand;

10. Spirit: e.g., awareness of oneself as human at different phases and situations of life.

According to Brooks, the listed issues can be considered central in terms of teaching cultural aspects of a target country, and, therefore, should also be taken into consideration by authors of teaching materials, as well as methodological materials for teachers. In addition, it is important that textbooks show how components of the target culture are reflected in the target language. Brooks also emphasizes that culture should already be integrated in the early phases of the FL learning process, which should be reflected in the teaching materials, as well.

Another set of goals for the teaching of culture, which should be taken into consideration by textbook publishers, was proposed by Lafayette (1997, p. 123). His list can be understood in terms of the ability of FL learners to recognize and explain issues, as follows: geographical monuments, historical events, major institutions (e.g., religious, political, etc.), artistic monuments (e.g., arts, literature, etc.), "active everyday cultural patterns" (e.g., eating, shopping, etc.), "passive" everyday cultural patterns (e.g., marriage, work), "culture of the target languagerelated ethnic groups" and "culture of non-European peoples speaking target language". In addition, FL learners should also be able to "act appropriately in common everyday situations, use appropriate common gestures and value different peoples and societies".

Apart from the mentioned goals, Lafayette (ibid., p. 128-134) also developed six basic principles for integrating language and culture both in FL teaching materials and in FL classrooms, as follows:

1. "Cultural objectives and activities must be planned as carefully as their language counterparts and be specifically included in lesson plans.

2. Cultural components must be tested as seriously as their language counterparts.

3. Textbook photographs must be considered as viable teaching content.

4. Language teaching must emphasize the teaching of content as much as it does the teaching of forms.

5. The teaching of culture must extend beyond factual learning and include community resources, experiential learning and process skills.

6. The target language should be the primary vehicle used to teach culture".

Stern (1992, p. 219-221) defines the content of cultural teaching in six areas, covering aspects which FL learners should have some familiarity with. They include, as follows: geographical places, i.e., physical location to which FL learners 
are able to relate the target language; people and way of life, i.e., how they live, what they do and think; people and society, i.e., social, professional and economic groups; history; institutions; as well as art, music and other achievements. Stern also emphasizes that teachers who do not want to neglect these issues need accessible and reliable sources. However, there is a lack of publications, especially in terms of certain aspects, e.g., everyday life in the target cultures.

Finally, as Skopinskaja (2003, p. 52) puts it "the existence of cultural input in the teaching materials does not automatically entail its exploitation", and it is up to the teachers how a particular course-book is used. It means that they should know how interculturally useful the course-book in question can be. For this reason, on the one hand, teachers should be acquainted with the basic principles of evaluating and selecting course-books; on the other hand, research analysing FL coursebooks should be extended to help teachers identify interculturally appropriate teaching materials.

\section{Analysing the cultural content in FL course-books}

In order to analyse the cultural content of FL textbooks several checklists have been proposed. For instance, Byram (1989) and Huhn (1978) distinguish the following seven criteria dealing with the cultural content of FL textbooks:

- Cultural information must be accurate and contemporary;

- The question of stereotypes must be handled critically;

- It must provide a realistic picture of the foreign society;

- It must be free from ideologies;

- Facts should not be presented in isolation;

- The historical material should be presented explicitly.

Another set of criteria is provided by Risager (1991, p. 182-183) and they can be divided into four main groups. "The micro level - phenomena of social and cultural anthropology includes the social and geographical definition of characters, material environment, situations of interaction, as well as interaction and subjectivity of the characters: feelings, attitudes, values, and perceived problems". "The macro level - social, political, and historical matters", as the second category comprises "broad social facts about contemporary society (geographical, economic, political, etc.), broad socio-political problems (unemployment, pollution, etc.) and historical background". The third group of criteria, i.e. "international and intercultural issues", consists of "comparisons between the foreign country and the pupils' own, mutual representations, images, stereotypes, as well as mutual relations: cultural power and dominance, cooperation and conflict". Finally, "the point of view and style of the author" also has to be taken into consideration. 
According to Cunningsworth $(1984,1995$, p. 92) the social and cultural context in the FL course must be comprehensible to the students and they should be able to interpret "the relationships, behaviour, intentions, etc. of the characters portrayed in the book". His checklist also pays special attention to gender differences, e.g. it is important to examine whether women are treated equally to men, what inner qualities and physical attributes women are given, and what professional and social status women have. Other aspects focus on the inner lives of the characters portrayed in the course and the social background against which they exist. Similar criteria are also listed by Kilickaya (2004), that is, "sociocultural information, learners' needs, stereotypes, generalisations and intercultural communication".

The model proposed by Cortazzi and Jin (1999, in Aliakbari, 2005) serves for investigating the type of culture which is presented in a particular FL course-book. They distinguish between the following three basic types of FL course-books:

1. FL course-books that reflect the source culture, i.e. FL learners' first culture;

2. FL course-books that reflect the target culture, i.e. cultures where the target language is spoken as first language;

3. FL course-books that reflect international target cultures, i.e. cultures where the target language is spoken as second or foreign language;

Damen's "textbook evaluation guide" (1987, p. 272) is divided into three parts. The first is focused on general information about the cultural content and its presentation; in addition, a number of questions is used, such as what specific cultural items are covered or how and through what method they are presented. The second part serves for the evaluation itself, i.e. giving personal opinion through answering a list of questions, e.g. whether the information is authentic, unbiased or problem-oriented, etc. Finally, the last part is designed to summarise the cultural load.

A further model for analysing the cultural content in FL textbooks was presented by Hatoss (2004). It resulted from a pilot study carried out as a content analysis of textbooks for English business communication within European context. The model focuses on the evaluation of three dimensions: text and visual input, methods used to teach the cultural content and aims set by the author/s or publisher/s of a particular textbook for developing learners' intercultural competence. Input factors include sociolinguistic and pragmatic competences, sociocultural knowledge, as well as paralinguistic and semiotic input. With regard to the methods, implicit versus explicit as well as cognitive versus experiential teaching of the cultural input are concerned, and the criterion of the authors/publishers' aims deals with the issue of assimilation.

Apart from the provided checklists, another set of categories and labelling codes was created by Reid (2014), who investigated how different aspects of ICC 
were implemented in teaching EFL at Slovak primary schools. In document analysis, she compared Slovak curricular documents with the CEFR, which also served as a core document for setting the categories and codes. Similarly to the previous checklist (by Hatoss, ibid.), hers takes into consideration all the aspects of ICC as described in CEFR (2001). Therefore, the present analysis of the intercultural component in the chosen FL course-book package will be carried out drawing on both Hatoss's and Reid's model.

\section{Research methodology}

The main aim of the research was to discover which aspects of the intercultural component in the New Opportunities course-book packages were relevant because suitably treated in terms of developing ICC at B1 level (according to the CEFR), while suitability was understood in terms of the requirements which FL learners were expected to fulfil according to European and Slovak key documents in the field of FL education. In addition, based on the model of Hatoss (2004), the particular aspects of the intercultural component in the selected course-book packages were considered as appropriate if they were treated both implicitly and explicitly in a sufficient extent. Furthermore, the structure of the codes, i.e. the equal representation of the functions comprised within the codes, were also taken into consideration.

Drawing on the methodology of several empirical studies (e.g. Byram,1989, Risager,1991, Aliakbari, 2005, Mineshima, 2008, Si Thang Kiet Ho, 2009, Juan, 2010, Kim, 2012, Liu, 2012, Oñate and Amador, 2013, Melliti, 2013), content analysis was selected as the main research method. However, as it is considered crucial not to rely merely on the analysis of a given teaching material, the method of triangulation was applied, i.e. the method of content analysis was supplemented by the methods of observation and interview.

In addition, both European and Slovak key documents in the field of FL education were analysed, in order to explore what specific requirements should be fulfilled by EFL course-books to be suitable for B1 level in terms of developing ICC. For the purpose of the documents analyses four documents were selected, as follows: the CEFR (ibid.) and Threshold 1990 (van Ek - Trim, ibid.), as well as the Slovak curricular documents, namely: The Slovak National Curriculum for the English Language ISCED 3 (Gadušová, 2011) and The Goal Standards for students taking school leaving exam of English language at level B1 (Štátny pedagogický ústav, 2012).

The results of the document analyses served to fine-tune the research instrument (See Appendice 1) for application in the course-book package analyses, the aim of which was to identify which aspects of the intercultural component were relevant because treated suitably in terms of developing ICC at B1 level. The sample consisted of materials that prepared secondary school FL learners for B1 
level of language proficiency (according to the CEFR), namely: New Opportunities Pre-Intermediate Student's Book (Harris, 2006b) and New Opportunities Intermediate Student's Book (Harris, 2006a), New Opportunities PreIntermediate Language Power-book (Reilly, 2006) and New Opportunities Intermediate Language Power-book (Sharman, 2006) functioning as workbooks, as well as New Opportunities Pre-Intermediate Teacher's Book (Mugglestone, 2006b) and New Opportunities Intermediate Teacher's Book (Mugglestone, 2006a).

In order to prove the suitability/unsuitability of the aspects of intercultural component in the New Opportunities Pre-Intermediate and Intermediate coursebook packages, in the next phase of the research, further data were collected through applying the method of observation. The aim of this phase of the research was to reveal which aspects of the intercultural component were developed suitably and sufficiently in the EFL lessons through the New Opportunities PreIntermediate and Intermediate course-book packages. With regard to the methodology of the observations, the sample comprised fifty EFL lessons observed at four different types of secondary schools in Nitra. All the lessons were taught by teachers regularly using the New Opportunities Pre-Intermediate and Intermediate Student's Books and Language Powerbooks. The selected materials were used during all the fifty lessons, either as the only teaching source or supplemented by other materials. During the observations, an observation schedule and the technique of field notes have been applied. Prior to the data analysis, the collected data have been categorised according to two principles: whether an ICC component was taught through the investigated student's books and workbooks, or through using other materials. However, the sample for the content analysis only contained the data achieved from the former group, i.e. the aspects developed by the examined course-book packages. The subsequent analysis has been carried out through applying the same set of categories and codes as course-book package and interview analyses. Similarly to the coursebook packages, both explicit and implicit treatment of the particular aspects, and the representation of the functions within the set of components have been taken into consideration.

The aim of the interviews was to find out which aspects, in teachers' view, of the intercultural component in the New Opportunities Pre-Intermediate and Intermediate course-book packages were relevant because suitably treated in terms of developing ICC at B1 level. With regard to the procedure of the interviews, the sample comprised twelve teachers who used the New Opportunities PreIntermediate and Intermediate Student's Books and Language Powerbooks on a daily basis. The set of categories and codes, applied in the course-book package analyses as well as observation data analyses, served as a basis for the semistructured interviews, upon which the open-ended schedule was built. In addition, 
the predefined categories and codes were used for the analyses of the collected data.

Finally, the findings of the course-book analyses were juxtaposed with the results of the observations and interviews. However, as the research was primarily concerned with the content of FL course-books, and not with the content of FL lessons or with teaching techniques, content analysis was regarded as the central method of the research. In addition, since the reliability of the results gained from both the observation and the interview analyses could be distorted by the teachers, (in the sense that they might have spoken and acted in a different way during the lessons than they normally would have), in case of contradictory results, the findings of the course-book package analyses were considered more reliable than those gained from the observation or the interview analyses. However, in case of contradictory results both from the observation and the interview analyses, the reliability of the findings of the course-book package analyses was questioned.

\section{Results and discussion}

Below the findings of the course-book package analyses are contrasted with the results of the observation and interview analyses within each category of the applied research instrument, i.e. within the category of sociolinguistic, pragmatic, sociocultural and intercultural competence.

\section{Sociolinguistic competence}

It may be assumed that the treatment of none of the components of linguistic markers of social relations (codes No 1, 3: greetings, addressing, expletives and fillers), can be considered as suitable in the New Opportunities Pre-Intermediate and Intermediate course-book packages. Even though greetings (code No 1) and expletives/fillers (code No 3) occured relatively frequently, due to their almost exclusively implicit character it can be assumed that they were not treated suitably in both the course-book package and in the EFL lessons. What is more, the interviewed teachers' opinions also supported this finding. In addition, even though some explicit attention was paid to formal and informal ways of addressing (code No 2), the results of all the three sources indicated they were not sufficient; hence, its treatment was identified as merely partially suitable.

Similarly, the treatment of the aspect of politeness conventions (codes No 4-7: positive and negative politeness, appropriate use of please, thank you and similar expressions, impoliteness), may be considered as unsuitable or only partially suitable. Specifically, the teachers indicated that the course-books treated positive and negative politeness (codes No 3-4) to an acceptable extent, the results of both the course-book analyses and the observations however proved that they were not presented almost at all, or merely implicitly. In addition, the treatment of please, 
thank you and similar expressions as well as impoliteness expressions (codes No 6-7), despite the teachers' views and the relatively high number of their occurrence during the observations, can be regarded as rather unsuitable, as these sociolinguistic markers were almost exclusively treated implicitly.

As far as expressions of folk wisdom (code No 8) are concerned, some controversy can be seen in the results of the three methods. Although both the course-book analyses and the observed lessons showed that they were treated both explicitly and implicitly to a sufficient extent, surprisingly, the teachers considered their treatment only partially suitable. They pointed out that there was lack of practice for the development of this issue, in addition, proverbs and quotations were not catered for at all. However, these statements may be contradicted, as every unit in the investigated student's books and workbooks contains at least one exercise focused on phrasal verbs; in addition, discussing the meaning of a proverb or a quote is a regular task in the New Opportunities PreIntermediate and Intermediate Student`s Books. Furthermore, the discourses of the analysed materials were also rich in idioms and phrasal verbs. Therefore, the treatment of the given aspect can be found suitable in terms of developing ICC at B1 level.

In connection to register differences (code No 9), a high consensus can be seen, as these were treated not only implicitly, but also explicitly both in the coursebooks and during the observed lessons. In addition, teachers also claimed that they were satisfied with the extent of attention given to this issue. What is more, in correspondence with the Slovakian and European key documents, the majority of the discourses were written in neutral style. Furthermore, the differences between informal and formal registers were also catered for sufficiently.

Finally, the treatment of dialect and accent (code No 10) differences can be considered only partially suitable, due to relatively little attention paid to the differences between the varieties of English. However, in accordance with the Slovakian and European key documents, the dominant accent of the course-book package was RP and FL learners could also experience listening to some other standard varieties, as well as to slightly-coloured regional speech.

\section{Pragmatic competence}

The results of all the three methods proved that the treatment of discourse competence, imparting and seeking factual information, expressing and finding out factual attitudes (codes No 11-13) and expressing modality can be identified as suitable in terms of developing ICC at B1 level. They were catered for both implicitly and explicitly and to a sufficient extent not only in the course-book packages, but also during the EFL lessons, in which the given materials were used. In addition, the teachers' opinions supported the appropriateness of these codes. 
Although both the teachers and the EFL lessons proved the opposite, expressing emotions (code No 17) was not suitably treated in either component of the coursebook package. With expressing knowledge (code No 14), expressing volition (code No 16) and suasion (code No 18) the interviewees claimed that they were appropriately catered for, on the other hand, the results of the content analyses and the observation showed that that they were either treated implicitly, and if treated explicitly, only to a lesser extent. Therefore, the presentation of these aspects can only be regarded as partially suitable.

Treatment of socialising (code No 19) and communication repair (code No 21) can be regarded as not suitable in terms of developing ICC at B1 level, both in case of the course-book packages and the EFL lessons. In addition, the interviewed teachers also agreed on neglect of these components throughout the course. Similarly, with structuring discourse (code No 20) and interaction schemata (codes No 22) they expressed dissatisfaction with the extent of treatment in the investigated course-book packages. Although some examples of the given codes could be traced both in the course-book package and during the observations, their treatment cannot be regarded as particularly suitable.

\section{Sociocultural competence}

Unlike the results of the course-book analyses, the treatment of low culture everyday living and high culture - arts (codes No 23-24), based on the teacher's opinions and the observations proved that knowledge of the given aspects can be extended to a significant extent with the help of the chosen teaching materials. It may be explained by the fact that, on the one hand, everyday life issues and information on arts occurred to a relatively great extent mainly in comparison with the other components of sociocultural knowledge. However, the investigated functions of low culture - everyday living were represented very unequally as the majority of the information focused on sports and media. On the other hand, all the examined issues comprised in the high culture - arts aspect occurred almost equally frequently and covered a lot of facts related to film, literature and music. Hence, despite partial appropriateness in representing low culture - everyday living and high culture - arts, their treatment can be regarded as suitable.

Living conditions (code No 25) and social conventions and rituals (code No 28), in the interviewed teachers' opinions, were treated partially suitably; however, neither the course-book analyses nor the observations supported this viewpoint. Both aspects can be thus regarded as rather unsuitable. In addition, interpersonal relations, major values and attitudes, and body language (code No 27-29) cannot be considered appropriate either, as it was revealed in all the three types of investigation.

In terms of the treatment of prosodic qualities (code No 30) rather controversial results were identified. Firstly, although treated both explicitly and implicitly and 
adequately in the investigated student's books, their overall treatment was evaluated as only partially suitable, due to inappropriate attention given to them in the workbooks. However, in the teachers' views, their representation was assessed as suitable. Yet, during the observed lessons they were given negligible attention. The explanation may be found in the teachers' attitude in other words, the teachers simply did not tackle the issues of stress and intonation during the observations at all. To sum up, despite the discussed findings, the treatment of prosodic qualities can be considered as suitable.

\section{Intercultural competence}

Generally, it is possible to conclude that the representation of none of the aspects of intercultural competence was particularly relevant in terms of developing ICC at B1 level. Nevertheless, it cannot be said that they were not catered for at all. Even though the other components of the course-book package (workbooks and the teacher's book) did not devote significant attention to them, the role of the first culture and understanding of similarities and differences between the target and the home culture (codes No 31-32) were treated to a relatively sufficient extent in the student's books. As opposed to these results, according to the majority of the teachers, none of the aspects was suitably treated. In addition, none of the four aspects occurred during the EFL lessons either; neither when the New Opportunities nor when the supplementary materials were used. Thus, it might be concluded that in terms of the teaching objectives, intercultural competence was not ranked as teachers' priority. In addition, it also evokes the idea that the interviewees might not be completely aware of the potentials which the investigated course-book packages possess; since comparing the target and the home culture, as well as making students aware of their own culture were regular issues within the so called "Culture Corner" sessions comprised in every unit.

\section{Conclusion}

Based on the above summarised findings and in order to draw conclusion, it seems to be reasonable to create three groups of the examined codes. The first group includes those aspects of the intercultural component whose representation and treatment may be considered as relevant because suitably treated in terms of developing ICC at B1 level in the New Opportunities Pre-Intermediate and Intermediate course-book packages, such as: expressions of folk wisdom (code No 8), register differences (code No 9), discourse competences, imparting and seeking factual information, expressing and finding out factual attitudes (codes No 11-13), expressing modality (code No 15), expressing emotions (code 17), high culture - arts (code No 24), prosodic qualities (code No 30). 
The second group comprises so called partially relevant aspects (i.e. treated either to an insufficient extent or chiefly implicitly), as follows: addressing (code No 2), dialect and accent (code No 10), expressing knowledge (code No 14), expressing volition (code No 16), suasion (code No 18), structuring discourse (code No 20), interaction schemata (codes No 22), low culture - everyday living, the role of the first culture and understanding of similarities and differences between the target and the home culture (codes No 31-32).

Finally, the third group contains aspects whose representation and treatment were identified as irrelevant because unsuitably treated (i.e. treated both to an insufficient extent and chiefly implicitly), such as: greetings (code No 1), expletives/fillers (code No 3), positive and negative politeness, appropriate use of please, thank you and similar expressions, impoliteness (codes No 4-7), socialising (code No 19), communication repair (code No 21), living conditions (code No 25), social conventions and rituals (code No 28), interpersonal relations, major values and attitudes, and body language (codes No 27-29), overcoming stereotypes and fostering cultural sensitivity (codes No 33-34).

\section{Recommendations}

In the light of the results, the following recommendations might be worth taking into consideration.

First of all, teachers using the New Opportunities Pre-Intermediate and Intermediate Course-book Packages should be presented the results of the present study showing that some ICC aspects (See above) are suitably developed. However, it also seems to be advisable that teachers be instructed in ways of exploiting the course-book potential to the maximum or be given advice about the ways of exploiting other sources. Secondly, teachers using the investigated teaching material should be trained how to cope with the insufficient treatment of some ICC aspects (See above). In addition, they should be also instructed how to supplement the course-book with other materials and activities in order to develop the abovementioned ICC aspects effectively. Furthermore, teachers using the given coursebook packages should be informed about the fact that some ICC aspects (See above) are not treated appropriately in these course-book passages. Hence, they should be encouraged to use extra materials and activities in order to develop these aspects effectively. Moreover, teachers who want to select suitable coursebook packages should be encouraged to opt for such packages that cater for a variety of ICC aspects suitably. Last but not least, teachers should be motivated to regularly participate in methodology seminars or workshops in order to keep up with the latest research findings and improve their skills both in terms of developing ICC and evaluating course-book packages. In addition, they should be motivated to constantly expand their own knowledge of the target country culture. 
As far as course-book writers are concerned, it seems to be of significant importance that they be informed about the research on this area (including the present research findings), about the aim of FLE today, which is to develop interculturally competent speakers of a given language; hence, the aspects of ICC need to be taken into consideration when writing course-books. In addition, course-book writers should be familiarised with the research findings indicating that the given aspects be treated both implicitly and explicitly and be offered sufficient practice in order to be developed effectively. Finally, the authors of teacher's books should learn about the necessity to provide detailed and adequate methodological guidance and especially, sufficient background knowledge on all the aspects of ICC, (not only high culture, i.e. arts).

Finally, with regard to teacher training programmes, it seems to be essential that EFL methodology courses to EFL teacher trainees pay considerable attention to the development of the given ICC aspects. Secondly, within the EFL methodology, undergraduate students should also be trained in terms of evaluating and selecting course-book packages that would contribute to the development of ICC. In addition, they should be taught how to supplement or replace unsuitable parts of course-book packages.

\section{References}

Aliakbari, M. (2005). The Place of Culture in the Iranian ELT Textbooks in High School Level. [Electronic version]. Proceedings of the 9th Pan-Pacific Association of Applied Linguistics Conference, 9 (1), 1-14. Retrieved from <http://www.paaljapan.org/resources/proceedings/2004/Aliakbari.pdf>.

Brooks, N. (1997). Teaching Culture in the Foreign Language Classroom. In Heusinkveld, P.R. (Eds.), Pathways to culture: Readings on Teaching Culture in the Foreign Language Class. Yarmouth: Intercultural Press, 11- 37.

Brown, H.D. (2000). Principles of Language Learning and Teaching. White Plains, NY: Addison Wesley Longman.

Buttjes, D. (1991). Mediating Languages and Cultures: the Social and Intercultural Dimension Restored. In Buttjes, D. - Byram, M. (Eds.), Mediating Languages and Cultures: Towards an Intercultural Theory of Foreign Language Education. Clevedon: Multilingual Matters, 3-16.

Byram, M. (1989). Cultural Studies in Foreign Language Education. Clevedon: Multilingual Matters.

Byram, M. (1991).Young people's perception of other cultures: the role of foreign language teaching. In Buttjes, D. - Byram, M. (Eds.), Mediating Languages and Cultures: Towards an Intercultural Theory of Foreign Language Education. Clevedon: Multilingual Matters, 103-119.

Byram, M. (1997). Teaching and Assessing Intercultural Communicative Competence. Clevedon: Multilingual Matters. 
Council of Europe. (2001). A Common European Framework of Reference for Language Learning, Teaching, Assessment (CEFR). [Electronic version]. Retrieved from <http://www.coe.int/t/dg4/linguistic/Source/Framework_EN.pdf>.

Corbett, J. (2003). An Intercultural Approach to English Language Teaching. Clevedon: Multilingual Matters.

Cunningsworth, A. (1984). Evaluating and Selecting EFL Teaching Materials. Oxford: Heinemann International.

Damen, L. (1987). Culture Learning: The Fifth Dimension in the Language Classroom. Reading: Addison-Wesley Publishing Company.

Davcheva, L., \& Sercu, L. (2003). Culture in Foreign Language Teaching Materials. In Sercu, L. (Eds.), Foreign Language Teachers and Intercultural Competence. Clevedon: Multilingual Matters, 90-109.

Gadušová, Z. (2011). Štátny vzdelávací program. Anglický jazyk. Príloha ISCED 3. Úroveř B1. Bratislava: Štátny pedagogický ústav.

Hall, J.K. (2002). Teaching and Researching Language and Culture. Harlow: Pearson Education Limited.

Harris, M. (2006a). New Opportunities Intermediate Student's Book. Essex: Pearson Education Limited.

Harris, M. (2006b). New Opportunities Pre-Intermediate Student's Book. Essex: Pearson Education Limited.

Hatoss, A. (2004). A model for evaluating textbooks. [Electronic version]. Babel 39(2), 25-32. Retrieved from <http://eprints.usq.edu.au/1137/3/Hatoss_Babel_2004_PV.pdf>.

Homolová, E. (2003). Autentický materiál ako prostriedok rozvoja jazykových a komunikatívnych kompetencí žiakov. Banská Bystrica: UMB.

Jong, W. (1996). Open frontiers: Teaching English in an intercultural context. Oxford: Reed Educational and Professional Publishing Ltd.

Juan, W. (2010). A Content Analysis of the Cultural Content in the EFL Textbooks. [Electronic version]. Canadian Social Science, 6(5), 137-44. Doi: http://dx.doi.org/10.3968\%2Fj.css.1923669720100605.016 .

Kachru, B.B., \& Nelson, C.L. (1996). World Englishes. In McKay, S.L., \& Hornberger, N.H. Sociolinguistics and Language Teaching. Cambridge: Cambridge University Press, 71 -102.

Kilickaya, F. (2004). Guidelines to evaluate cultural content in textbooks. [Electronic version]. The Internet TESL Journal, 10 (12). Retrieved from $<$ http://iteslj.org/Techniques/Kilickaya-CulturalContent/>.

Kvetko, P. (1996). English Lexicology. Bratislava: PF UK.

Kim, H. (2012). Social and cultural issues in some EFL textbooks in Korea. [Electronic version]. Hawaii Pacific University TESOL Working Paper Series 10, 30-39. 
<http://www.hpu.edu/CHSS/LangLing/TESOL/ProfessionalDevelopment/20 1210_TWPfall12/TESOL_WPS_2012_Kim.pdf>.

Lafayette, R. C. (1997). Integrating the Teaching of Culture into the Foreign Language Classroom. In Heusinkveld, P.R. (Eds.), Pathways to culture: Readings on Teaching Culture in the Foreign Language Class. Yarmouth: Intercultural Press, 119-148.

Liu, S. (2010). Cultural Content in EFL Listening and Speaking Textbooks for Chinese University Students. [Electronic version]. International Journal of English Language Education, 1(1), 82-93. Doi: 10.5296/ijele.v1i1.2850 .

Liu, S. et al. 2011. Introducing Intercultural Communication. Global Cultures and Contexts. London, SAGE.

Melliti, M. (2013). Global Content in Global Coursebooks: The Way Issues of Inappropriacy, Inclusivity, and Connectedness Are Treated in Headway Intermediate. SAGE Open, 1-12. Doi: 10.1177/2158244013507265.

Mineshima, M. (2008, October). Gender Representations in an EFL Textbook. [Electronic version]. Bulletin of Niigata Institute of Technology, 13(1), 121-40. Retrieved from <http://www.niit.ac.jp/lib/contents/kiyo/genko/13/14_MINESHIMA.pdf>.

Mugglestone, P. (2006a). New Opportunities Intermediate Teacher's Book. Essex: Pearson Education Limited.

Mugglestone, P. (2006b). New Opportunities Pre-Intermediate Teacher's Book. Essex: Pearson Education Limited.

Oñate, C. L., \& Amador, M. V. (2013). The intercultural component in Business English textbooks. [Electronic version]. Ibérica, 26, 171-194. Retrieved from $<$ http://www.aelfe.org/documents/08_26_Lario.pdf>.

Reid, E. (2014). Intercultural Aspects in Teaching English at Primary Schools. Frankfurt am Main: Peter Lang Edition.

Reilly, P. (2006). New Opportunities Pre-Intermediate Language Powerbook. Essex: Pearson Education Limited.

Risager, K. (1991). Cultural References in European Textbooks: An Evaluation of Recent Tendencies. In Buttjes, D., \& Byram, M. (Eds.), Mediating Languages and Cultures: Towards an Intercultural Theory of Foreign Language Education. Clevedon: Multilingual Matters, 181-92.

Sándorová, Z. (2013). Traditional and Computer-based Teaching Aids and Learning Resources in Foreign Language Education in Slovakia. Journal of Language and Cultural Education 1 (1), 86-111.

Saville-Troike, M. (1996). The ethnography of communication. In McKay, S.L., \& Hornberger, N.H. (Eds.), Sociolinguistics and Language Teaching. Cambridge: Cambridge University Press, 351-382. 
Seelye, H. N. (1997). Foreword. In Heusinkveld, P.R. (Eds.), Pathways to culture: Readings on Teaching Culture in the Foreign Language Class. Yarmouth: Intercultural Press.

Sercu, L. (2005). Foreign Language Teachers and Intercultural Competence. Clevedon: Multilingual Matters.

Sharman, E. (2006). New Opportunities Intermediate Language Powerbook. Essex: Pearson Education Limited.

Si Thang Kiet Ho. (2009). Addressing Culture in EFL Classrooms: The Challenge of Shifting from a Traditional to an Intercultural Stance. [Electronic version]. Electronic Journal of Foreign Language Teaching, 6(1), 63-76. Retrieved from <http://e-flt.nus.edu.sg/v6n12009/ho.pdf>.

Skopinskaja, L. (2003). The role of culture in foreign language teaching materials: an evaluation from an intercultural perspective. In Lazar, I. (Eds.), Incorporating intercultural communicative competence in language teacher education. Strasbourg Cedex: Council of Europe, 39-69.

Štátny pedagogický ústav. (2012). Ciel'ové požiadavky na vedomosti a zručnosti maturantov z anglického jazyka úroveň $B 1$.

Stern, H.H. (1992). Issues and Options in Language Teaching. Oxford: Oxford University Press.

Van Ek, J.A. \& Trim, J.L.M. (1998). Threshold 1990. Cambridge: Cambridge University Press.

\section{Contact}

Mgr. Zuzana Sándorová, PhD.

Department of Tourism, Faculty of Central European Studies,

Constantine the Philosopher University in Nitra

Dražovská 4, Nitra 949 74, Slovakia

zsandorova@ukf.sk 


\section{Appendix}

Aspects of intercultural communicative competence with assigned codes used in the content analyses based on the CEFR (ibid.), Threshold 1990 (ibid.), ISCED 3 (ibid.) and the Goal Standards (ibid.)

\begin{tabular}{|c|c|c|}
\hline CATEGORY & CODE N. & CODE \\
\hline \multirow{10}{*}{$\begin{array}{l}\text { Sociolinguistic } \\
\text { competence }\end{array}$} & 1 & Greetings (CEFR, ibid., p. 119) \\
\hline & 2 & Addressing (ibid.) \\
\hline & 3 & $\begin{array}{l}\text { Using expletives (ibid.) and fillers (SERR, ibid., } \\
\text { p.120) }\end{array}$ \\
\hline & 4 & Positive politeness (CEFR, ibid.) \\
\hline & 5 & Negative politeness (ibid.) \\
\hline & 6 & $\begin{array}{l}\text { Appropriate use of thank you and please } \\
\text { (ibid.) }\end{array}$ \\
\hline & 7 & Impoliteness (ibid., p. 119-120) \\
\hline & 8 & Expressions of folk wisdom (ibid., p. 120) \\
\hline & 9 & Register differences (ibid.) \\
\hline & 10 & Dialect, accent (ibid., p. 121) \\
\hline \multirow{12}{*}{$\begin{array}{l}\text { Pragmatic } \\
\text { competence }\end{array}$} & 11 & Discourse competence (ibid., p. 123) \\
\hline & 12 & $\begin{array}{l}\text { Imparting and seeking factual information } \\
\text { (ibid., 126) }\end{array}$ \\
\hline & 13 & $\begin{array}{l}\text { Expressing and finding out factual attitudes } \\
\text { (ibid., p. 126) }\end{array}$ \\
\hline & 14 & Expressing knowledge (ibid.) \\
\hline & 15 & Expressing modality (ibid.) \\
\hline & 16 & Expressing volition (ibid.) \\
\hline & 17 & Expressing emotions (ibid.) \\
\hline & 18 & Suasion (ibid.) \\
\hline & 19 & Socialising (CEFR, ibid., van Ek - Trim, ibid.) \\
\hline & 20 & $\begin{array}{l}\text { Structuring discourse (van Ek - Trim, ibid., p. } \\
42-45 \text { ) }\end{array}$ \\
\hline & 21 & $\begin{array}{l}\text { Communication repair (van Ek - Trim, ibid., p. } \\
45-47 \text { ) }\end{array}$ \\
\hline & 22 & Interaction schemata (ibid., p. 126) \\
\hline \multirow[t]{4}{*}{$\begin{array}{l}\text { Sociocultural } \\
\text { competence }\end{array}$} & 23 & $\begin{array}{l}\text { Low culture - Everyday living (van Ek - Trim, } \\
\text { ibid., p. 95) }\end{array}$ \\
\hline & 24 & High culture - arts (CEFR, ibid., ) \\
\hline & 25 & Living conditions (van Ek - Trim, ibid.) \\
\hline & 26 & Interpersonal relations (ibid., p. 96) \\
\hline
\end{tabular}


slovakEdu, o.z.

\begin{tabular}{|l|l|l|}
\hline \multirow{5}{*}{$\begin{array}{l}\text { Intercultural } \\
\text { competence }\end{array}$} & 27 & Major values and attitudes (ibid., p. 96) \\
\cline { 2 - 3 } & 28 & Social conventions and rituals (ibid.) \\
\cline { 2 - 3 } & 29 & Body language(ibid.) \\
\cline { 2 - 3 } & 31 & $\begin{array}{l}\text { Prosodic qualities (ibid.) } \\
\text { Role of first culture in developing ICC - } \\
\text { Reinforcing cultural identity }\end{array}$ \\
\cline { 2 - 3 } & 32 & $\begin{array}{l}\text { Understanding of the similarities and } \\
\text { differences between the target and the home } \\
\text { culture; }\end{array}$ \\
\cline { 2 - 3 } & 33 & $\begin{array}{l}\text { Fvercoming stereotypes } \\
\text { cultures }\end{array}$ \\
\cline { 2 - 3 } & 34 &
\end{tabular}

